\title{
The cell toxicity effect of secalonic acid $D$ on GH3 cells and the related mechanisms
}

\author{
GUIZHI LIAO $^{1,4}$, JING ZHOU ${ }^{1}$, HUI WANG ${ }^{1}$, ZHIGANG MAO $^{2}$, WEIWEI XIAO ${ }^{1}$, \\ HAIJUN WANG ${ }^{2}$, ZHIGANG $\mathrm{SHE}^{3}$ and YONGHONG ZHU ${ }^{1}$ \\ ${ }^{1}$ Department of Histology and Embryology, ${ }^{2}$ Department of Neurosurgery, the First Affiliated Hospital, ${ }^{3}$ Department of \\ Chemistry and Chemical Engineering, Sun Yat-sen University, Guangzhou, Guangdong 510080, ${ }^{4}$ Department of \\ Neurosurgery, Guangzhou General Hospital of Guangzhou Military Command, Guangzhou 510010, P.R. China
}

Received July 22, 2009; Accepted September 21, 2009

\section{DOI: 10.3892/or_00000647}

\begin{abstract}
To investigate the anti-pituitary adenoma effect of secalonic acid D (SAD) extracting from marine microorganisms, we used MTT colorimetric method to evaluate the proliferation of $\mathrm{GH} 3$ cells treated by $\mathrm{SAD}$, the time- and dose-dependent effects and the value of $\mathrm{IC}_{50}$ were recorded. Hoechst staining, TUNEL and flow cytometry methods were used to analyze the apoptosis rate of GH3 cells treated by SAD. Western blotting, RT-PCR and caspase inhibitor (ZVAD-FMK) were used to investigate the possible mechanism of SAD induced apoptosis and the expression of growth hormone $(\mathrm{GH})$. The results showed that SAD has a time- and dose-dependent effect on GH3 cells and the cytotoxic effect was mainly through apoptosis. The mechanisms were partly through the activity of caspase family and also G1/S phase block. In addition, SAD also can suppress the expression levels of growth hormone in GH3 cells, however, the RTPCR results showed that the mechanism was not through changing the expression of GH mRNA. We concluded that SAD may be a potential anti-pituitary tumor drug and further in vivo studies should be performed.
\end{abstract}

\section{Introduction}

The pituitary gland located in Hypophyseal Fossa is composed of neurohypophysis and adenohypophysis. It is a central endocrine organ that have important functions in maintaining homeostasis, controling hormone recycle, and activating the

Correspondence to: Dr Yonghong Zhu, Department of Histology and Embryology, Zhongshan School of Medicine, Sun Yat-sen University, Guangzhou, Guangdong 510080, P.R. China E-mail: zhuyongh@mail.sysu.edu.cn

Dr Zhigang She, Department of Chemistry and Chemical Engineering, Sun Yat-sen University, Guangzhou, Guangdong 510080, P.R. China E-mail: cesshzhg@mail.sysu.edu.cn

Key words: marine fungi drug, pituitary adenoma, apoptosis, growth hormone, cell cycle block other gland organs. It can regulate the systems of growth and metabolism cooperated with the nervous system (1). A mutation on adenohypophysis always induces several important systems dysplasia or dysfunction through parasecretion or suppressing surrounding tissues. Patients suffer a very poor life quality with pituitary adenoma and the final diagnosis and rational therapy are quite difficult because of the different differentiation states of tumor cells. Pituitary adenoma always occur in young adults and have severe influence on growth development, daily work and fertility, unsuitable diagnosis and treatment will bring a great burden on the patients, family and the society.

According to studies from the US and Italy, clinically diagnosed pituitary adenoma occur with a prevalence of 1928 cases/100,000 population (4), being $10 \%$ of the central nervous system tumors (2-4). Clinical diagnosis is established 5-10 years after the development of a pituitary adenoma, because most of the tumors are benign and grow very slowly and no obvious symptoms exist. Ezzat et al (5) undertook a systematic review of all autopsy and radiological studies of the prevalence of pituiray adenomas, they found that the mean prevalence was $\sim 16.7 \%$ or one in six individuals. Such a high morbidity attracted more reseach attention. Surgical resection is the main treatment of pituitary adenoma, while drug therapy was an important adjunctive treatment. With the development of pathogenesis research and new drugs, the position of pharmacotherapy has became increasingly important. Some therapies efficiently suppress volume of the tumors and the hyper-secreting hormone, such as bromocriptine, somatropin analogue $(6,7)$. However, Chanson et al (8) pointed out that there are hardly any effective drugs for non-functioning pituitary adenomas (NFAs), while Somatostatin analogues are effectively only on GH adenoma expressing SSTR2 or SSTR5 and no obvious effect on other subtypes $(9,10)$.

Marine endophytic fungi have been proven to be a rich source of new biologically active natural products for they present a relatively untapped ecological environment, and their secondary metabolism molecules was particularly active because of the interactions with their hosts. Remarkably, many of these biologically active molecules have potential utility in modern medicine and biomedical research. Marine 
natural products, which were isolated from sponges, microorganisms and tunicates are currently in clinical or preclinical trials for the treatment of tumors $(11,12)$. However, few researchers have reported on the medical treatment of pituitary adenoma from marine products. We report on an effective marine fungi compound for pituitary adenoma cells. The compound used in our experiment is a marine natural product extracted from Paecilomyces sp. (tree 1-7) and SBE14 of South China Sea (13), and we found that the compound has the same struture as secalonic acid D (SAD) (Fig. 1). Although there are studies on the antitumor effects such as leukemia (14), bladder carcinoma (15), no research on pituitary adenoma was found. We found a significant supression of GH3 cells (rat pituitary adenoma cell line) on cell proliferation and $\mathrm{GH}$ expression treated by SAD.

\section{Materials and methods}

Chemicals and reagents. SAD was provided from the Department of Chemistry and Chemical Engeering of Sun Yat-sen University (16). GH3 cell line was purchased from ATCC (USA). Anti-rat GH antibody and anti-rat B-actin anibody were purchased from Santa Cruz Biotechnology. Horseradish peroxidase (HRP)-conjugated sencondary antibody was purchased from Invitrogen Biotechnology. TUNEL kit purchased from Roch Biotechnology.

Cell culture. The rat pituitary adenoma cell line GH3 cells were cultured in complete medium (F-10 supplemented with $15 \%$ horse serum and $2.5 \%$ FBS) as previous described (17). Complete medium was changed every 2-3 days, and transfer of culture (1:2-3) every 6-7 days by $0.25 \%$ trypsogen- $0.02 \%$ EDTA. The cells were plated at a density of $1 \times 10^{6} /$ well in a 6-well plate for Western blotting, $1 \times 10^{5} /$ well in a 24 -well plate for radioimmunological kit, $2 \times 10^{4} /$ well in a 96 -well plate for cell proliferation experiment.

MTT assay. The cell proliferation of SAD treated on GH3 cells were measured by MTT assay. Briefly, GH3 cells were seeded on 96-well plates (Corning, USA) in the presence of various concentration of SAD $\left(10^{-8}-10^{-4} \mathrm{M}\right)$ for $48 \mathrm{~h}$ as a pre-experiment. Then, different concentration of SAD $\left(1.25 \times 10^{-7}, 2.5 \times 10^{-7}, 5 \times 10^{-7}, 10 \times 10^{-7}, 20 \times 10^{-7}, 40 \times 10^{-7} \mathrm{M}\right)$ were treated on $\mathrm{GH} 3$ cells in a final volume of $100 \mu 1$ for indicated times. Thereafter, $10 \mu 1 \mathrm{MTT}(5 \mathrm{~g} / \mathrm{l})$ was added to each well and incubated for $2 \mathrm{~h}, 100 \mu \mathrm{l}$ developer solution (SDS w/v 20\%; isopropanol v/v 10\%; 1 M hydrochloric acid v/v $2 \%$ ) was added and incubated overnight at $37^{\circ} \mathrm{C}$. Optical density was determined at $570 \mathrm{~nm}$ by using a microplate reader. The following formula was used: cell proliferation inhibited $(\%)=[1-(\mathrm{OD}$ of the experimental samples $/ \mathrm{OD}$ of the control) $] \times 100 \% ; \operatorname{IgIC}_{50}=\mathrm{Xm}-\mathrm{I}(\mathrm{P}-(3-\mathrm{Pm}-\mathrm{Pn}) / 4 ; \mathrm{Xm}$, maximal dose; I, maximal dose/adjacent dose; $\mathrm{P}$, sums of positive reaction rate; $\mathrm{Pm}$, maximal positive reaction rate; Pn, minimal positive reaction rate.

Flow cytometric analysis of cell cycle and apoptosis. Cell cycle distribution and apoptosis was determined by staining DNA with propidium iodide (PI). Briefly untreated or SAD treated cells $(0.3 \mu \mathrm{M}$ for $12,24,48 \mathrm{~h})$ were centrifuged, washed

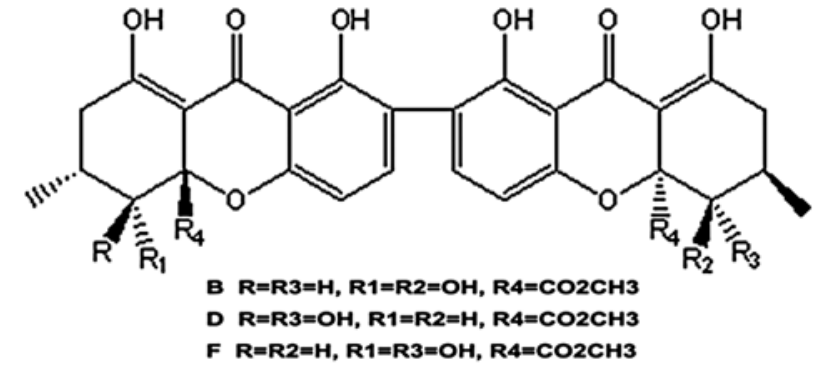

Figure 1. Structure of SAD.

with PBS and fixed in $70 \%$ pre-cooled ethanol. The tubes containing the fixed cells were stored at $4^{\circ} \mathrm{C}$ for at least $24 \mathrm{~h}$. After this, the cells were centrifuged at 1,500 rpm for $5 \mathrm{~min}$, and the supernatant was discarded to remove ethanol completely. The cells were washed by PBS and stained with PI solution [100 $\mu \mathrm{g} / \mathrm{ml}$ PI from $50 X$ stock solution $(2.5 \mathrm{mg} / \mathrm{ml})$, $0.1 \mathrm{mg} / \mathrm{ml} \mathrm{RNase} \mathrm{A,} 0.05 \%$ Triton X-100], incubated in the dark for $40 \mathrm{~min}$ at $37^{\circ} \mathrm{C}$. After $3 \mathrm{ml}$ PBS was added, the cells were pellet $(1,500 \mathrm{rpm}, 5 \mathrm{~min})$ and the supernatant was taken off. Then the pellet was resuspended with $500 \mu 1$ PBS for flow cytometric analysis. Cells with DNA content below G1 phase (peak of hypodiploid DNA below G1 phase) were regarded as apoptotic cells. The cells in G0/G1 phase, S phase and G2/M phase were analyzed by muticycle software.

Hoechst 33342 staining. Apoptotic bodies were observed by Hoechst 33342 staining. Briefly, SAD $\left(\mathrm{IC}_{50}\right)$ treated or untreated cell climbing slides were fixed in $4 \%$ paraformaldehyde at room temperature for $1 \mathrm{~h}$. Then the slides were washed with $3 \mathrm{X}$ PBS for $5 \mathrm{~min}$, and incubated with Hoechst $33342(50 \mu \mathrm{g} / \mathrm{ml})$ for 5-10 min in dark. Washed with 3X PBS for $5 \mathrm{~min}$ and the apoptotic bodies were observed under a fluorescence microscope.

TUNEL assay. The TUNEL methods was used as previously described (18) to assess the DNA fragmentation. Briefly, GH3 cells treated by SAD for different times were fixed for $1 \mathrm{~h}$ in $4 \%$ paraformaldehyde at room temperature. Endogenous peroxidase was inactivated by incubation with $3 \%$ hydrogen peroxide in methanol for $30 \mathrm{~min}$ at room temperature and further incubated in a permeabilizing solution $(0.1 \%$ Triton $\mathrm{X}-100)$ for $2 \mathrm{~min}$ at $4^{\circ} \mathrm{C}$. The cells were incubated with the TUNEL reaction mixture for $60 \mathrm{~min}$ at $37^{\circ} \mathrm{C}$, followed by labeling with peroxidase conjugated anti-fluorescein anti-sheep antibody Fab fragments for additional $30 \mathrm{~min}$. TUNEL-positive cells were green under fluorescence microscope and brown with DAB (3,3'-diaminobenzidine tetrahydrochloride) staining. The apoptotic rate of SAD-treated cells was caculated by the formula: (apoptotic rate $=$ TUNEL-positive cells/(TUNEL-positive cells + TUNEL-negative cells) $\times 100 \%$.

RT-PCR analysis for expression of GH $m R N A$. Total RNA of GH3 cells treated by SAD for indicate times were extracted using TRIzol reagent (Takara Bio-Tek, Dalian, China). Briefly, the RT-PCR method was used as previously discribed (19). For RT, the SuperScript first-strand synthesis system kit 


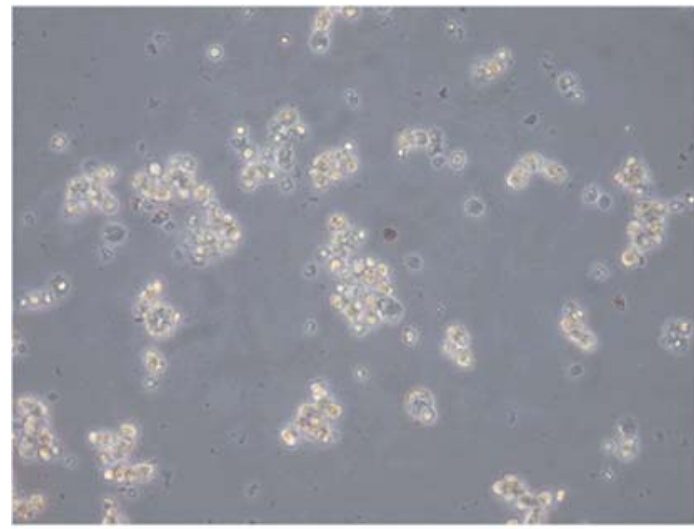

A

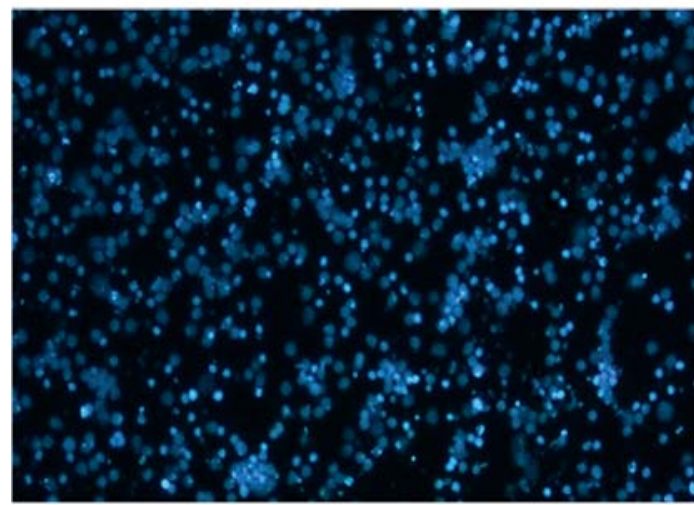

C

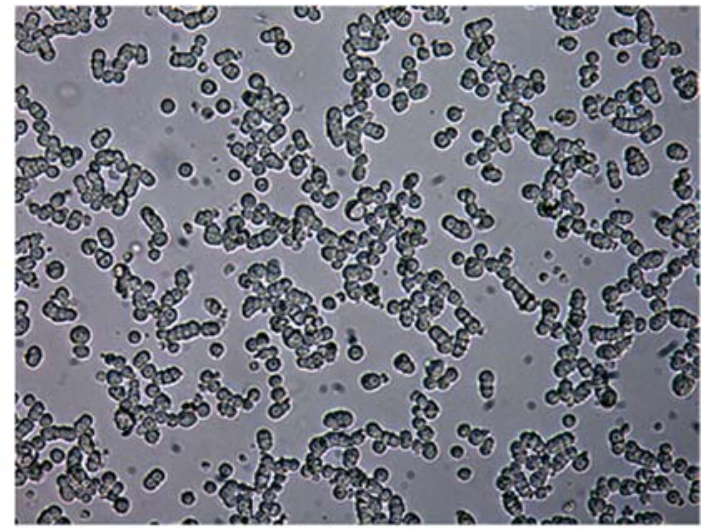

B

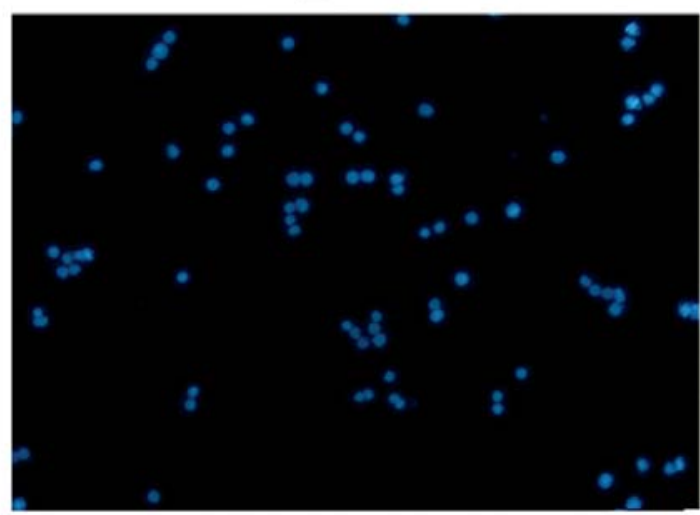

D

Figure 2. GH3 cells cultured with F10 complete culture medium (A) compared with incubated with SAD for 48 h (B). Most of the cells treated with SAD were floating after treated with STb, and the cytoplasm split into small pieces. Apoptotic cells were observed by Hoechst 33342 staining (C) which were incubated with $0.3 \mu \mathrm{M} \mathrm{SAD}$ for 24 h. (D) Normal GH3 cells stained by Hoechst 33342 (x100, bar, $40 \mu \mathrm{M}$ ).

(Invitrogen) was used. RT products (cDNA) $(2 \mu 1)$ were amplified with $\mathrm{GH}$ primers as follows: $\mathrm{GH}$ sense primer: 5'-ACTCCCTGGCTCCTGACCTT-3', GH antisense primer: 5'-GGATGAGCAGCAGCGAGAA-3'. These primers were designed by Primer Premier 5.0 software. The predicted product is $307 \mathrm{bp}$. Amplification was carried out as follows: $1 \mathrm{x}\left(10 \mathrm{~min}\right.$ at $\left.94^{\circ} \mathrm{C}\right), 35 \mathrm{x}\left(45 \mathrm{sec}\right.$ at $94^{\circ} \mathrm{C}, 45 \mathrm{sec}$ at $56.5^{\circ} \mathrm{C}$, and $45 \mathrm{sec}$ at $\left.72^{\circ} \mathrm{C}\right)$, and $1 \mathrm{x}\left(5 \mathrm{~min}\right.$ at $\left.72^{\circ} \mathrm{C}\right)$. A portion $(5 \mu \mathrm{l})$ of RT-PCR product was electrophoresed in $1 \%$ agarose gel in Tris-acetate-EDTA buffer. The gel was stained with ethidium bromide and photographed using Bio-imaging system (Sygene Genegenius, USA).

Western blot analysis. Aliquots (60 $\mu \mathrm{g}$ of protein) of cell lysates were separated on $12 \%$ SDS-PAGE, blotted onto a PVDF membrane (Bio-Rad, USA). Membranes were washed twice with $0.05 \%$ Tween-20 in TBS (pH 7.6) and then incubated with blocking buffer (5\% non-fat milk in TBST) for $60 \mathrm{~min}$. Overnight incubation of membranes with primary antibodies (anti-rat GH 1:1000, anti-rat B-actin 1:2000) were done at $4^{\circ} \mathrm{C}$, then washed 3 times with TBST. Membranes were incubated with secondary antibodies at room temperature for $60 \mathrm{~min}$, washed 3 times with TBST and antibody bound proteins were detected by enhanced chemiluminescence reagents (Pierce).
Caspase inhibition assay. Whether SAD induced GH3 cell apoptosis through caspase pathway was further measured using an MTT based assay. Briefly, the cells (10000/well) were incubated in a 96-well plate. Caspase inhibitor Z-VADFMK $(20 \mu \mathrm{M})$ was added $15 \mathrm{~min}$ before $\mathrm{SAD}\left(\mathrm{IC}_{50}\right)$ in a final volume of $100 \mu \mathrm{l}$ and incubated for different times (12, 24, $36,48 \mathrm{~h}$ ). One control was the absence of caspase inbitor and the other was absence of SAD and the caspase inhibitor. Then the inbibition effects were measured by MTT analysis.

Statistical analysis. Data are presented as the mean \pm SD per group. Statistical analysis was performed using Student ttest and ANOVA followed by multiple comparison tests. $\mathrm{P}<0.05$ was considered to be statistically significant. Experiments, both the treated group and the control, were carried out in triplicate.

\section{Results}

SAD inhibits pituitary adenoma cell proliferation in a dosedependent manner. We investigated the effect of SAD on $\mathrm{GH} 3$ cell proliferation. GH3 cells were treated with SAD in a dose-dependent manner $(0.125-4.0 \mu \mathrm{M})$ and cell proliferation was assessed by MTT assay after incubated for $48 \mathrm{~h}$. After treatment with $\mathrm{SAD}\left(\mathrm{IC}_{50}\right)$ for $48 \mathrm{~h}$, the morphology was changed (Fig. 2A and B). The cells shrunk, got smaller, 

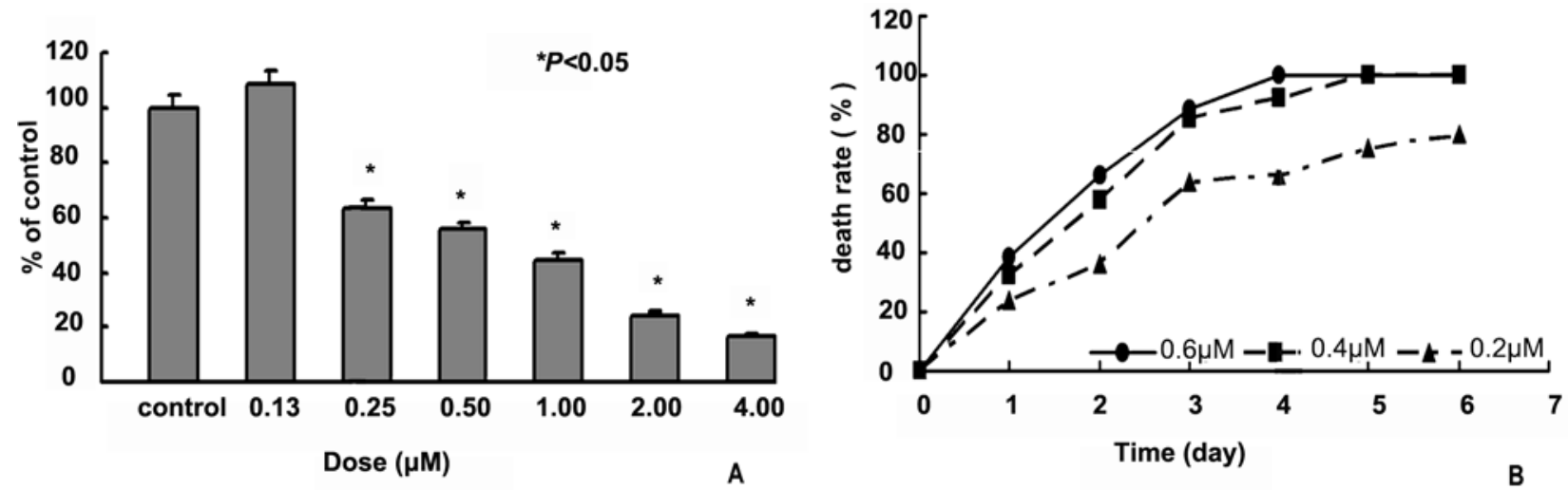

Figure 3. GH3 cells were treated with indicated concentration of $\mathrm{SAD}(4.0,2.0,1.0,0.5,0.25,0.125 \mu \mathrm{M})$. When the dilution range of $\mathrm{SAD}$ was $0.25-4.0 \mu \mathrm{M}$, the proliferation was in a dose-dependent manner decreased (A). (B) Three different concentrations of SAD $(0.2,0.4,0.6 \mu \mathrm{M})$ were treated on GH3 cells for 6 days and cell proliferation was assessed by MTT method, $\left({ }^{*} \mathrm{P}<0.05\right)$.
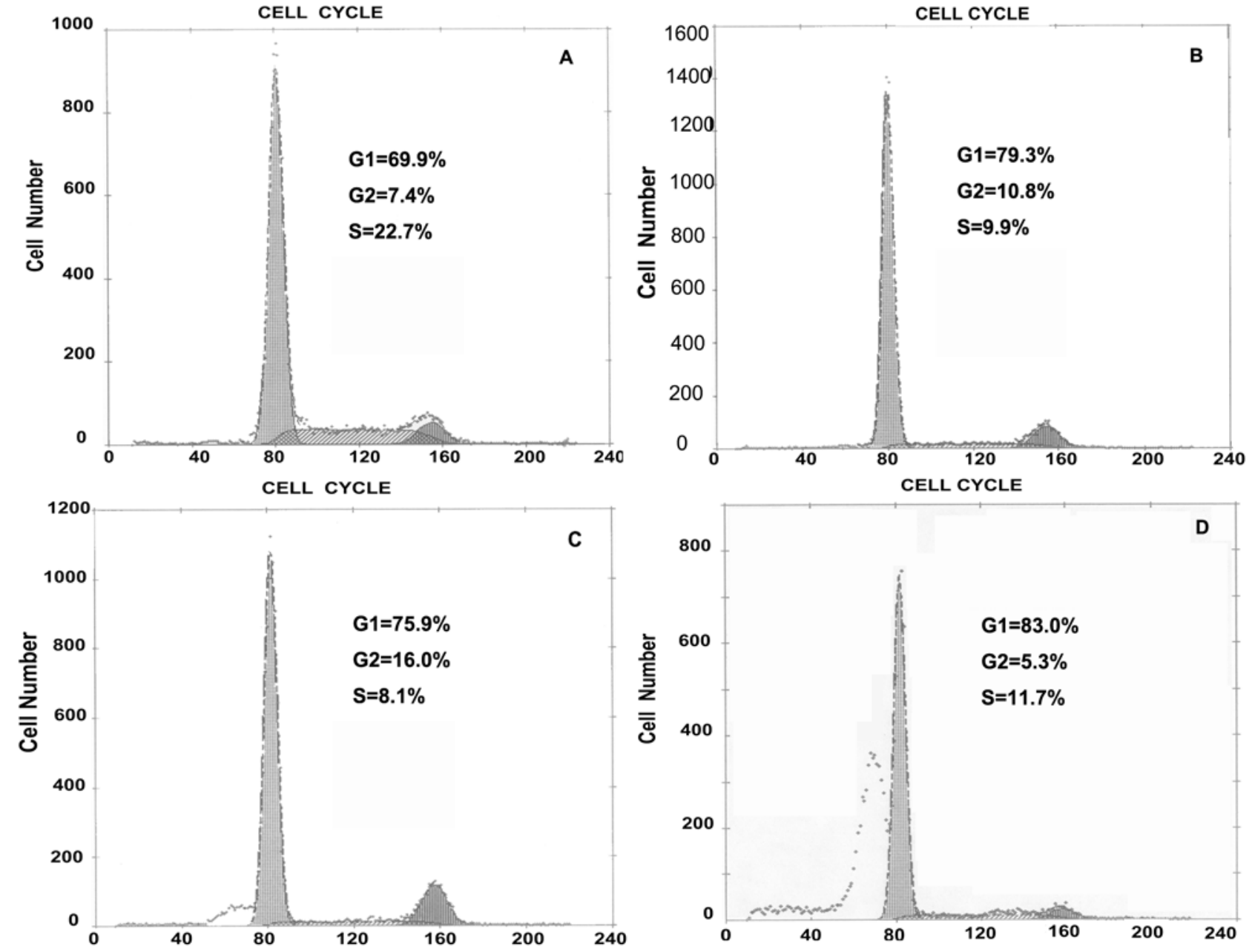

Figure 4 . The cell cycle phase were observed on GH3 cells treated by SAD $(0.3 \mu \mathrm{M})$ for $0,12,24,48 \mathrm{~h}$. The results indicate that with longer incubating time, the percent of G1 phase increased and S phase decreased compared with the control group $(0 \mathrm{~h})$.

broke into smaller pieces, and most of the cells were floating compared with the control. The results of MTT assay showed that SAD, in a dose-dependent manner inhibited GH3 cell proliferation (Fig. 3A). With the rise of SAD concentration, the cell survival rate decreased gradually. When the cells were treated with $4 \mu \mathrm{M}$ for $48 \mathrm{~h}$, only $20 \%$ survived compared with the control, however, when the concentration was diluted to $0.125 \mu \mathrm{M}$, there was hardly any toxic effects on GH3 cells. We calculated the $50 \%$ inhibition concentration $\left(\mathrm{IC}_{50}\right)$ as $0.357 \pm 0.083 \mu \mathrm{M}$. 

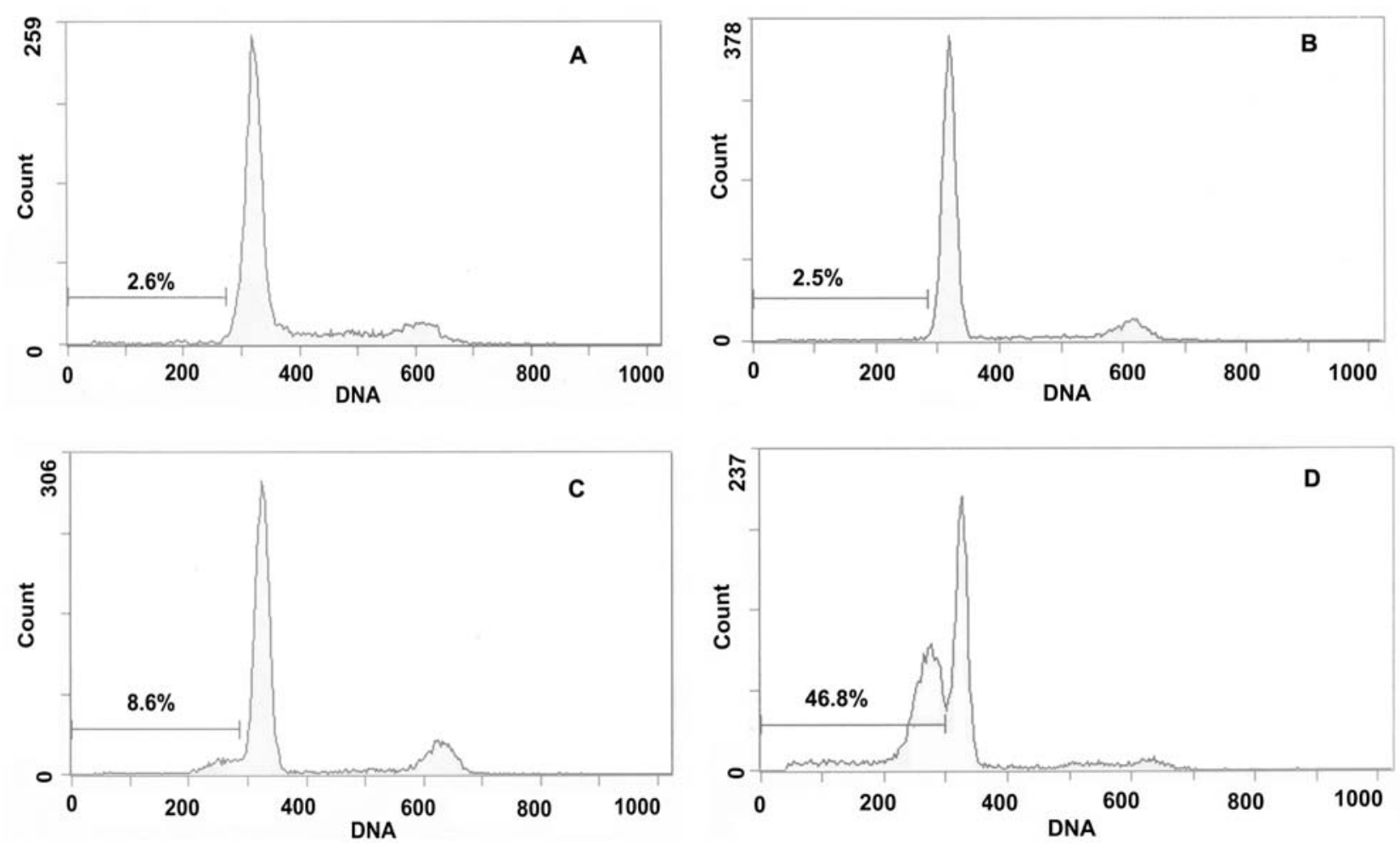

Figure 5. GH3 cells were treated with $\mathrm{SAD}\left(\mathrm{IC}_{50}\right)$ for indicated times $(0,12,24,48 \mathrm{~h})$ by FCM, the hypodiploid DNA were considered as apoptotic cells and the apoptosis rates were $2.6,2.5,8.6,46.8 \%$, respectively. The apoptosis rate was significantly increased in the $24 \mathrm{~h}$ and $48 \mathrm{~h}$ groups $(\mathrm{P}<0.05)$.

SAD inhibits pituitary adenoma cell proliferation in a timedependent manner. We next determined the time-dependent manner treated with SAD for 6 days by MTT assay (Fig. 3B). The results indicated that SAD $(0.6 \mu \mathrm{M})$ incubated for 2 days can induced $\sim 70 \% \mathrm{GH} 3$ cells death, and after incubated for 4 days, nearly all cells died; SAD $(0.4 \mu \mathrm{M})$ incubated for 2 days can induced $\sim 60 \% \mathrm{GH} 3$ cells death, and after incubated for 5 days, nearly all cells died; SAD $(0.2 \mu \mathrm{M})$ incubated for 2 days can induce $\sim 30 \% \mathrm{GH} 3$ cell death, the maximal cell death rate $(80 \%)$ was achieved for 6-day incubation, and no significant changes after that (data not shown). We chose $0.3 \mu \mathrm{M}$ SAD incubated for $48 \mathrm{~h}$ as the best concentration and treatment time for the later experiments according to the $\mathrm{IC}_{50}$ and time-dependent experiments.

SAD induces pituitary adenoma cell changes of cell cycle and apoptosis in a time-dependent manner. We observed the GH3 cell cycle changes and the cell apoptosis rate treated with SAD through flow cytometric (FCM) analysis. After treatment with SAD $(0.3 \mu \mathrm{M})$ for $12,24,48 \mathrm{~h}$, the number of G0/G1 and G2/M phase in GH3 cells were significantly increased and decreased, respectively (Fig. 4). The cell proliferation inhibition likely blocked the cell cycle progression from $\mathrm{G} 1$ to $\mathrm{S}$ phase. The analysis of DNA contents by FCM showed the number of hypodiploid DNA (point to apoptosis) before $\mathrm{G} 1$ phase in $\mathrm{GH} 3$ cells treated by SAD for $12,24,48 \mathrm{~h}$ and control group were 2.5, 8.6, 46.8, 2.6\%, respectively (Fig. 5). The apoptosis rate was significantly increased in $24 \mathrm{~h}$ and $48 \mathrm{~h}$ groups, while no obviously changes in $12 \mathrm{~h}$ group compared with control group. The results showed that the SAD induced GH3 cells apoptosis in a timedependent manner.

Hoechst staining and TUNEL assay were also used to investigate whether treatment by SAD causes apoptosis or necrosis and the apoptosis rate. Apoptotic bodies were observed in SAD treated group with Hoechst staining and no apoptotic bodies were found in the control group (Fig. 2C and D). Cells with condensed, fragmented nuclei was scored as apoptotic. The apoptotic nature of these cells was comformed by TUNEL staining, TUNEL-positive cells showed brown color nuclei, and the apoptotic rate was calculated (Fig. 6). The apoptotic rates were 7.72, 8.68, $20.65,48.64 \%$, respectively, after SAD treatment for 0,12 , $24,48 \mathrm{~h}$, for the $24 \mathrm{~h}$ and $48 \mathrm{~h}$ groups the apoptotic rates had significant differences compared with the control (Fig. 7). TUNEL assay results were consistent with the results obtained from FCM analysis. The above indicated that the cell toxicity effect of SAD-induced GH3 cell death was mainly through apoptosis.

$S A D$ decreased growth hormone $(G H)$ expression levels in GH3 cells, but not the GH mRNA levels. We investigated whether SAD had an influence on hormone expression in GH3 cells by Western blot analysis and RT-PCR methods. GH3 cells were incubated with SAD for $0,12,24,48 \mathrm{~h}$, and $\mathrm{GH}$ content in equal amount of cell lysates was determined by Western blotting. Our results show (Fig. 8A) that SAD in a time-dependent manner decreased the expression of $\mathrm{GH}$ in $\mathrm{GH} 3$ cells, the expression of $\mathrm{GH}$ decreased at $12 \mathrm{~h}$, and nearly completely blocked GH expression after $48 \mathrm{~h}$ 


\section{Tunel assay results}
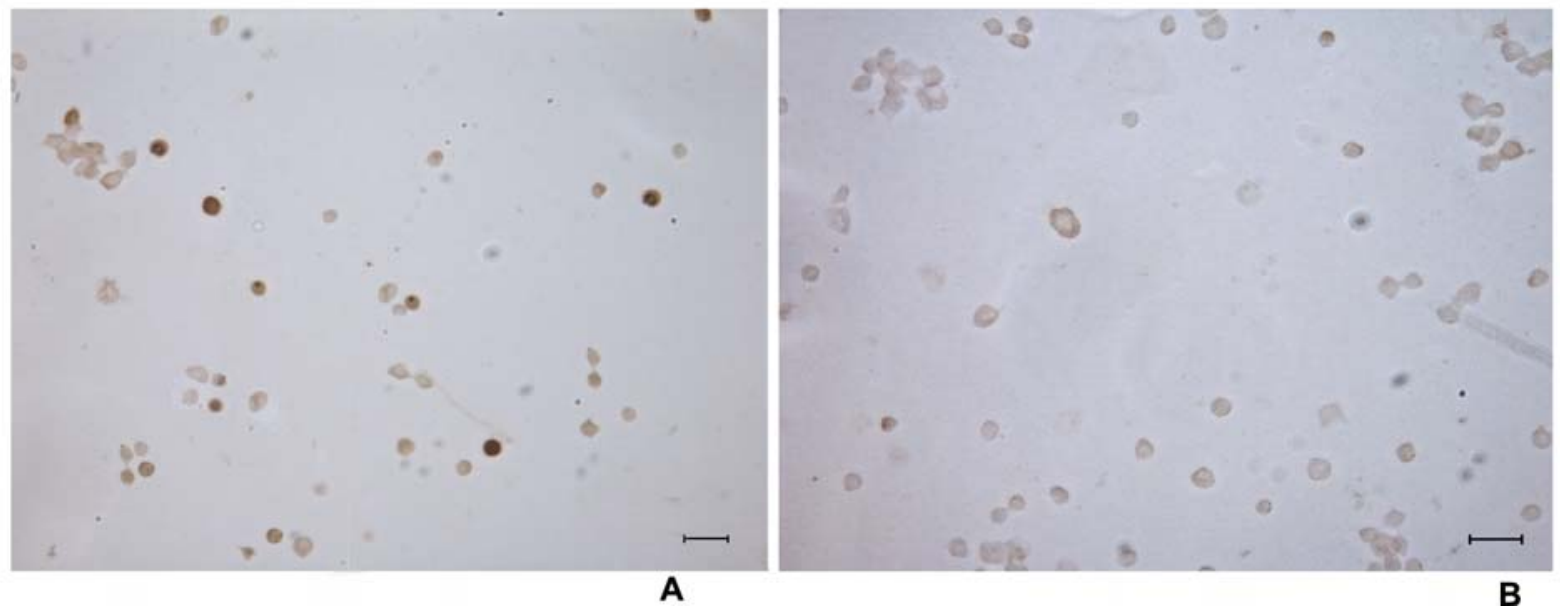

Figure 6. SAD-induced GH3 cell apoptosis was investigated by TUNEL assay. TUNEL-positive cells show dark brown nuclear, while the nuclear is light brown in the control group (x100).

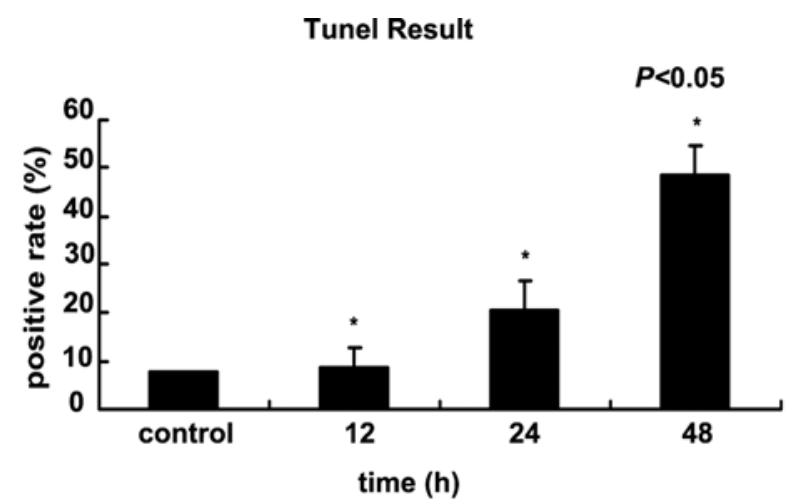

Figure 7. The apoptosis rate of different incubation times by SAD were calculated according to the result of TUNEL assay. The results showed that the apoptosis rate at $24 \mathrm{~h}$ and $48 \mathrm{~h}$ groups were significantly increased $\left({ }^{*} \mathrm{P}<0.05\right)$.

incubation. We also investigated whether the decreased expression of $\mathrm{GH}$ was through down-regulating mRNA level by RT-PCR, however, we found no significant changes of mRNA in $\mathrm{GH} 3$ treated with different concentrations $(0,1.0$, $0.5,0.25,0.125,0.65 \mu \mathrm{M})$ for $12 \mathrm{~h}$ (Fig. 8B). The results indicated that $\mathrm{SAD}$ can reduce $\mathrm{GH}$ protein expression through other than the mRNA level.

Caspase inhibitor Z-VAD-FMK can reduce the apoptosis rate induced by $S A D$. In order to explore whether the mechanism of SAD inducing GH3 cell apoptosis was through the caspase pathway. We added $20 \mu \mathrm{M}$ caspase inhibitor Z-VAD-FMK to $\mathrm{GH} 3$ cells treated by $\mathrm{SAD}\left(\mathrm{IC}_{50}\right)$ at different times and analyzed by MTT assay. The results showed that Z-VADFMK can partly inhibit SAD induced apoptosis at $36 \mathrm{~h}$ and 48 h (Fig. 9).

\section{Discussion}

Pituitary adenoma is a common benign tumor with several pathological effects due to excessive hormone secretion and tumor press the surrounding tissues. The incidence rate of pituitary adenoma is increasing, however, there are only two effective therapeutic drugs, Dopamine 2 (D2) agonists and a Somatostatin analogue. Moreover, it is reported that $\sim 10$ $25 \%$ nonfunction pituitary adenoma (NFPA) have no effect treated by D2 agonists bromocriptine (8), and 5-10\% patients have intolerance to the serious side-effects such as dizziness, nausea, and arrhythmia. Certain GH adenoma patients are also insensitive to Somatostatin analogue therapy $(9,10)$. Miller et al (20) found that curcumine, a commonly used food additive can effectively inhibit pituitary adenoma cell proliferation, induce apoptosis and decrease hormone secretion. Cervia et al (21) found that euplotin C, isolated from the ciliate Euplotes crassus can induce $\mathrm{Ca}^{2+}$ stores in the endoplasmic reticulum (ER), release of cytochrome $c$ from the mitochondria, activation of caspase-12, and activation of caspase-3, leading to apoptosis in pituitary adenoma ATt20 cells. In this study, we examined the role of SAD, a natural product extracted from marine fungi, that had a potential neurotoxicity effect on pituitary adenoma cells and induced cell apoptosis, moreover, SAD also can inhibit the expression level of $\mathrm{GH}$ in vitro.

Our data showed that SAD in a dose- and time-denpendent manner inhibited the proliferation of pituitary adenoma $\mathrm{GH} 3$ cells by MTT assay. The inhibitory effect of SAD $(0.3 \mu \mathrm{M})$ was apparent within $24 \mathrm{~h}$ of treatment, incubated for $48 \mathrm{~h}$ the inhibitory effect can achieve 50\%, and persist up to 6 days SAD can nearly completely block the proliferation of GH3 cells and induced cell death. The half inhibitory concentration was caculated as $0.357 \pm 0.083 \mu \mathrm{M}$ in our experiments, and we also compared the $\mathrm{IC}_{50}$ of many other marine compounds treated adenocarcinoma cells. Antipathine A, extacted from China Sea had a cell toxicity effect on gastric carcinoma (SGC-7901) cells, and the $\mathrm{IC}_{50}$ was $67.38 \mathrm{mg} / \mathrm{ml}$ (22); The $\mathrm{IC}_{50}$ of hantupeptin on leukemic cells (MOLT-4) and breast carcinoma cells (MCF-7) were 32 and $4.0 \mathrm{mM}$, respectively (23); the $\mathrm{IC}_{50}$ of kuanoniamine $\mathrm{A}$ and kuanoniamine $\mathrm{C}$ on MCF-7 cells were $0.12 \pm 0.07 \mu \mathrm{M}$ and $0.81 \pm 0.11 \mu \mathrm{M}$, respectively (24). We concluded that SAD 


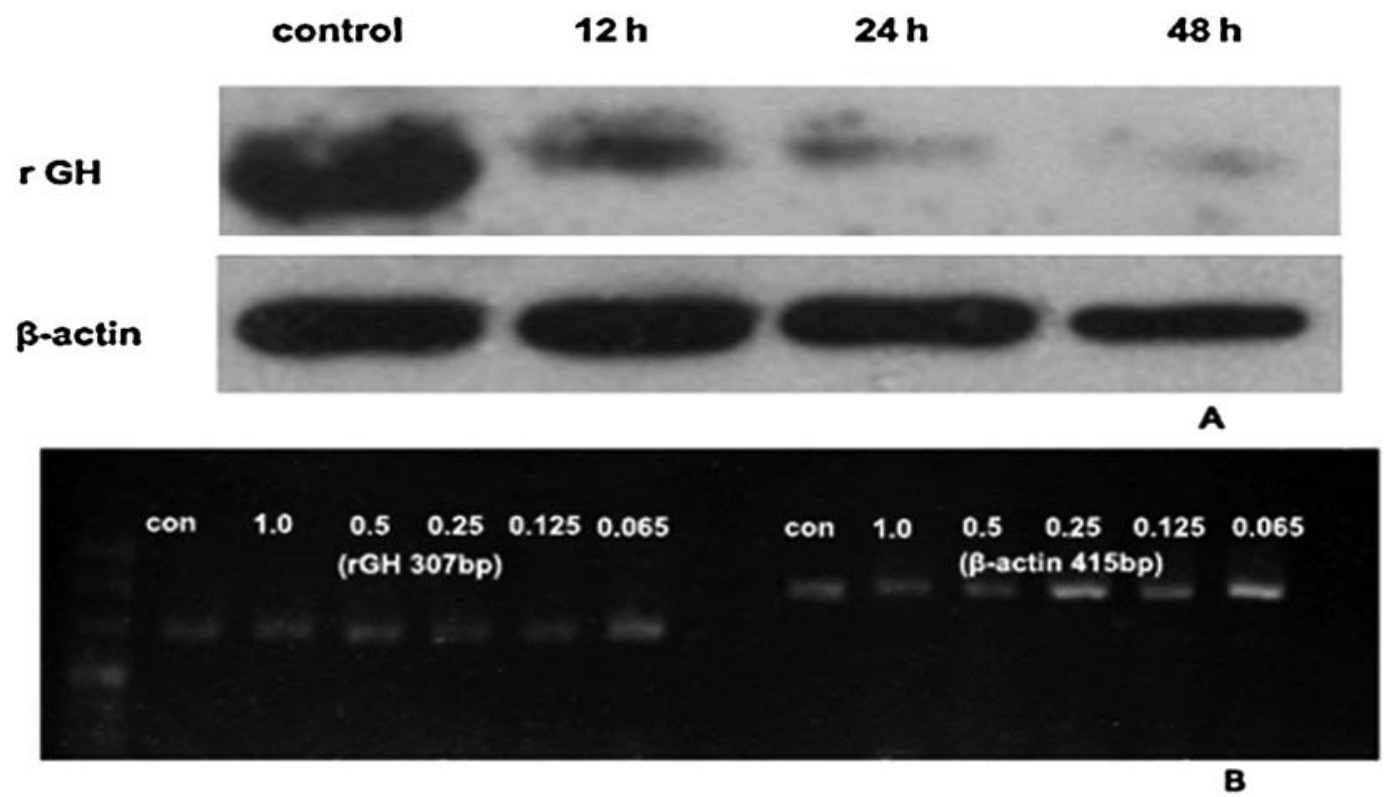

Figure 8. The expression of GH in GH3 cells treated with SAD for $0,12,24,48 \mathrm{~h}$ was assessed by Western blotting. The result showed that the expression of GH was time-dependently decreased (A); The changes of GH mRNA treated with SAD for different concentrations at $12 \mathrm{~h}$ were assessed. The results indicated that no significant changes of GH mRNA was oberved in GH3 cells treated with SAD compared to the control of $ß$-actin (B).

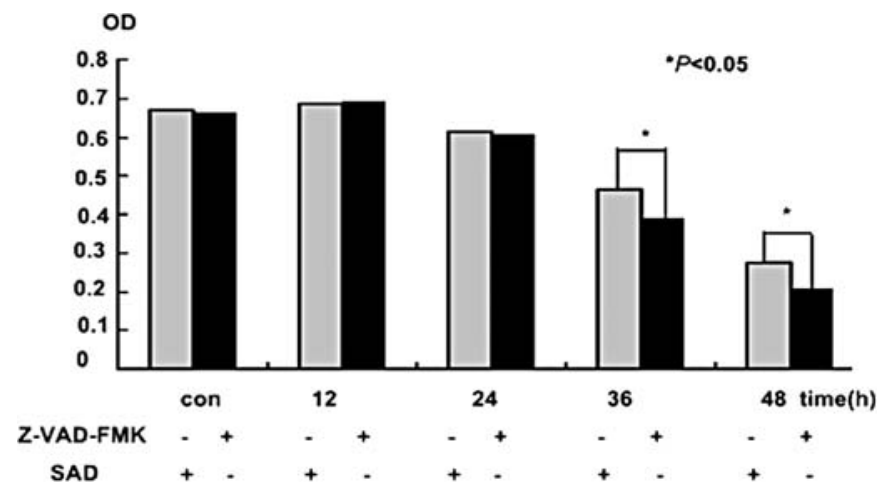

Figure 9. Caspase inhibitor Z-VAD-FMK $(20 \mu \mathrm{M})$ and $\mathrm{STb}(0.3 \mu \mathrm{M})$ were incubated with GH3 cells to assess the function of caspase family in the process of STb-induced cell apoptosis. The results indicated that caspase inhibitor can partly inhibit the death of GH3 cells treated by STb at $36 \mathrm{~h}$ and $48 \mathrm{~h}\left({ }^{*} \mathrm{P}<0.05\right)$.

had a much stronger inhibition effect on GH3 cells compared to the other anti-adenocarcinoma compounds.

Whether the inhibitory effect is through apoptosis or necrosis was further investigated by observing the apoptosis rate induced by SAD. Considerring that apoptosis plays a central role in regulation of pituitary tissue homeostasis, the imbalance between cell death and proliferation in favor of cell survival could result in tumor formation. One of the commonly employed strategies in clinical/experimental therapy for cancer is to trigger tumor cell apoptosis (25). Clinical chemotherapeutics, such as alkylating agents, cisplatin and paclitaxel, can suppress cell proliferation and induce tumor cell apoptosis (26). Therefore, whether SAD can induce GH3 cell apoptosis was a very important aspect for further research, and Hoechst 33342 staining, TUNEL assay, FCM were used to observe the apoptosis rate induced by SAD. The results showed that the cell toxicity effect of SAD was mainly through apoptosis, and in a time-dependent manner, therefore we believe that SAD may be an effective natural compound for promoting apoptosis. Moreover, the FCM also showed that SAD can block G1/S phase transition in the cell cycle reducing proliferation of GH3 cells, and initiating apoptosis.

It is clear that caspase family members play important roles in driving apoptosis. Activation of caspase appears for many of the moleculer and structural changes in apoptosis. There also exists an active caspase-independent programmed cell death (PCD), such as apoptosis inducing factor (AIF) and Endonuclease G $(27,28)$. SAD-induced apoptosis through caspase was determined by caspase inhibitor ZVAD-FMK. The results indicated that blocking caspase activity can partly reduce the apoptosis rate, however, only $\sim 20 \%$ cells survived in caspase inhibitor-treated group compared with the absence of caspase inhibitor group in different incubations. We concluded that the mechanism of SAD induced apoptosis was partly through the caspase pathway, but also through another pathway. AIF is believed to play a central role in the regulation of caspase-independent cell death and it is released from mitochondria in response to apoptotic stimuli (29).

Hyperprolectinemia and excessive levels of GH are commonly associated with pituitary adenoma. We questioned whether SAD had any effect on the levels of GH in GH3 cells. RT-PCR and Western blotting were used to investigate the changes of GH in mRNA level and protein level, respectively. Finally, we demonstrated that SAD had a potent timedependent inhibitory effect on GH expression in GH3 cells, but no significant changes were observed in GH mRNA incubated by different concentrations of SAD for $12 \mathrm{~h}$. This result suggests that SAD can modify the post-translational 
level and induces the reducing product of GH protein. Posttranslational modification of important gene products have a close association with tumorigenesis, and could become a new therapeutic target for tumors. Casado et al (30) found that vincristine regulated the phosphorylation of the antiapoptotic protein HSP27 in breast cancer cells and induced cancer cell apoptosis. There are many drugs such as tetracycline (31), chlormycetin (32), and erythrocin (32) that can inhibit the conjunction of aminoacyl-tRNA, transpeptidase and peptide formation. SAD may also affect organelles such as mitochondria, ribosome and endoplasmic reticulum, for pituitary adenoma cells have activity in synthesis and secretion of many kinds of hormones and abundance of organelles. It is reported that many important factors that regulate the expression of $\mathrm{GH}$ were synthesized and secreted in endoplasmic reticulum and Golgi such as Somatotropin release inhibiting factor (SRIF) (33), vascular endothelial growth factor (VEGF) (34), carboxypeptidase D (CPD) (35). SAD may indirectly influence these factors to reduce the expression of $\mathrm{GH}$.

In conclusion, we have shown for the first time that SAD inhibits proliferation, and induces apoptosis. In addition we show that SAD decrease cell proliferation and apoptosis may be through cell cycle blocking, via caspase activation. We also demonstrated that SAD suppresses intracellular $\mathrm{GH}$ hormone levels, but has no influence on mRNA level of GH in the first $12 \mathrm{~h}$ while the expression of GH protein declined. Based on these data, we propose that SAD may be a novel therapeutic compound in the management of GH adenomas, but further study is required.

\section{Acknowledgements}

We thank Professor M.F. Li and Professor Y.C. Lin from Sun Yat-sen University for their technical assistance. Guangdong Social Development Fields Program (2007A032600001).

\section{References}

1. Amar AP and Weiss MH: Pituitary anatomy and physiology. Neurosurg Clin N Am 14: 11-23, 2003

2. Davis FG, Kupelian V, Freels S, McCarthy B and Surawicz T: Prevalence estimates for primary brain tumors in the United States by behavior and major histology groups. Neuro Oncol 3: $152-158,2001$.

3. Davis JR, Farrell WE and Clayton RN: Pituitary tumours. Reproduction 121: 363-371, 2001.

4. Daly AF, Burlacu MC, Livadariu E and Beckers A: The epidemiology and management of pituitary incidentalomas Horm Res 68 (Suppl 5): 195-198, 2007.

5. Ezzat S, Asa SL, Couldwell WT, Barr CE, Dodge WE, Vance ML and McCutcheon IE: The prevalence of pituitary adenomas: a systematic review. Cancer 101: 613-619, 2004.

6. Schäffler A: Treatment of pituitary gland hyperfunction: from acromegaly to prolactinoma. Internist (Berl) 47: 1215-1222, 2006.

7. Chanson P, Borson-Chazot F, Chabre O, et al: Drug treatment of hyperprolactinemia. Ann Endocrinol (Paris) 68: 113-117, 2007.

8. Chanson $\mathrm{P}$ and Brochier S: Non-functioning pituitary adenomas. J Endocrinol Invest 28 (Suppl 11): 93-99, 2005.

9. Jallad RS, Musolino NR, Salgado LR and Bronstein MD: Treatment of acromegaly with octreotide-LAR: extensive experience in a Brazilian institution. Clin Endocrinol 63: 168-175, 2005 .
10. Bronstein M, Musolino N, Jallad R, Cendros JM, Ramis J, Obach R, Leselbaum A and Catus F: Pharmacokinetic profile of lanreotide Autogel in patients with acromegaly after four deep subcutaneous injections of 60,90 or $120 \mathrm{mg}$ every 28 days. Clin Endocrinol 63: 514-519, 2005.

11. Shao CL, Guo ZY, Xia XK, Liu Y, Huang ZJ, She ZG, Lin YC and Zhou SN: Five nitro-phenyl compounds from the South China Sea mangrove fungus. J Asian Nat Prod Res 9: 643-648, 2007.

12. Simmons TL, Coates RC, Clark BR, Engene N, Gonzalez D, Esguenazi E, Dorrestein PC and Gerwick WH: Biosynthetic origin of natural products isolated from marine microorganisminvertebrate assemblages. Proc Natl Acad Sci USA 105: 4587-4594, 2008.

13. Xia XK, Huang HR, She ZG, Shao CL, Liu F, Cai XL, Vrijmoed LL and Lin YC: (1)H and (13)C NMR assignments for five anthraquinones from the mangrove endophytic fungus Halorosellinia sp. (No. 1403). Magn Reson Chem 45:1006-1009, 2007.

14. Ren H, Tian L, Gu Q and Zhu W: Secalonic acid D: A cytotoxic constituent from marine lichen-derived fungus Gliocladium sp. T31. Arch Pharm Res 29: 59-63, 2006.

15. Iwaguchi $T$, Kitagawa $H$, Hirose $K$, Ishida $T$ and Yamamoto $T$ : 5-Di-(2'-tetrahydropyranyl)secalonic acid D as a new antibiotic derivative with anticancer activity. Div Chemother 71: 900-906, 1980.

16. Guo Z, Shao C, She Z, Cai X, Liu F, Vrijimoed LL and Lin Y: ${ }^{1} \mathrm{H}$ and ${ }^{13} \mathrm{C}$ NMR assignments for two oxaphenalenones bacillosporin $\mathrm{C}$ an $\mathrm{d} D$ from the mangrove endophytic fungus SBE-14. Magn Reson Chem 45: 439-441, 2007.

17. Bancroft FC and Tashjian AH Jr: Growth in suspension culture of rat pituitary cells which produce growth hormone and prolactin. Exp. Cell Res 64: 125-128, 1971.

18. Dong DL, Wang QH, Yue P, Jiao JD, Gu RM and Yang BF: Indapamide induces apoptosis of GH3 pituitary cells independently of its inhibition of voltage-dependent $\mathrm{K}^{+}$currents. Eur J Pharmacol 536: 78-84, 2006.

19. Emery MN, Leontiou C, Bonner SE, Merulli C, Nanzer AM, Musat M, Galloway M, Powell M, Nikeookam K, Korbonits M and Grossman AB: PPAR-gamma expression in pituitary tumours and the functional activity of the glitazones: evidence that any anti-proliferative effect of the glitazones is independent of the PPAR-gamma receptor. Clin Endocrinol (Oxf) 65: 389-395, 2006.

20. Miller M, Chen S, Woodliff J and Kansra S: Curcumin (diferuloylmethane) inhibits cell proliferation, induces apoptosis, and decreases hormone levels and secretion in pituitary tumor cells. Endocrinology 149: 4158-4167, 2008.

21. Cervia D, Martini D, Garcia-Gil M, Di Giuseppe G, Guella G, Dini F and Bagnoli P: Cytotoxic effects and apoptotic signalling mechanisms of the sesquiterpenoid euplotin C, a secondary metabolite of the marine ciliate Euplotes crassus, in tumour cells. Apoptosis 11: 829-843, 2006.

22. Qi SH, Su GC, Wang YF, Liu OY and Gao CH: Alkaloids from the South China Sea Black Coral Antipathes dichotoma. Chem Pharm Bull (Tokyo) 57: 87-88, 2009.

23. Tripathi A, Puddick J, Prinsep MR, Lee PP and Tan LT: Hantupeptin A, a cytotoxic cyclic depsipeptide from a Singapore collection of Lyngbya majuscula. J Nat Prod 72: 29-32, 2009.

24. Kijjoa A, Wattanadilok R, Campos N, Nascimento MS, Pinto M and Herz W: Anticancer activity evaluation of kuanoniamines A and $\mathrm{C}$ isolated from the marine sponge oceanapia sagittaria, Collected from the Gulf of Thailand. Mar Drugs 5: 6-22, 2007.

25. Bianco SR, Sun J, Fosmire SP, Hance K, Padilla ML, Ritt MG, Getzy DM, Duke RC, Withrow SJ, Lana S, Matthiesen DT, Dow SW, Bellgrau D, Cutter GR, Helfand SC and Modiano JF: Enhancing antimelanomaimmune responses through apoptosis. Cancer Gene Ther 10: 726-736, 2003.

26. Caponigro F, Basile M, de Rosa V and Normanno N: New drugs in cancer therapy, National Tumor Institute, Naples, 17-18 June 2004. Anticancer Drugs 16: 211-221, 2005.

27. Festjens N, Vanden Berghe $T$ and Vandenabeele P: Necrosis, a well-orchestrated form of cell demise: Signalling cascades, important mediators and concomitant immune response. Biochim Biophys Acta 1757: 1371-1387, 2006.

28. Boujrad H, Gubkina O, Robert N, Krantic S and Susin SA: AIFmediated programmed necrosis: a highly regulated way to die. Cell Cycle 6: 2612-2619, 2007. 
29. Cregan SP, Dawson VL and Slack RS: Role of AIF in caspasedependent and caspase-independent cell death. Oncogene 23: 2785-2796, 2004.

30. Casado P, Zuazua-Villar P, del Valle E, Martinez-Campa C, Lazo PS and Ramos S: Vincristine regulates the phosphorylation of the antiapoptotic protein HSP27 in breast cancer cells. Cancer Lett 247: 273-282, 2007.

31. Zakeri B and Wright GD: Chemical biology of tetracycline antibiotics. Biochem Cell Biol 86: 124-136, 2008.

32. Sutcliffe JA: Improving on nature: antibiotics that target the ribosome. Curr Opin Microbiol 8: 534-542, 2005.
33. Lee MA, Cheong KH, Shields D, Park SD and Hong SH: Intracellular trafficking and metabolic turnover of yeast preproalpha-factor-SRIF precursors in GH3 cells. Exp Mol Med 34: 285-293, 2002

34. Vidal S, Oliveira MC, Kovacs K, Scheithauer BW and Lloyd R: Immunolocalization of vascular endothelial growth factor in the GH3 cell line. Cell Tissue Res 300: 83-88, 2000.

35. Varlamov O, Wu F, Shields D and Fricker LD: Biosynthesis and packaging of carboxypeptidase D into nascent secretory vesicles in pituitary cell lines. J Biol Chem 274: 14040-14045, 1999. 